\title{
A Study of Metacognitive Awareness of Non-English Majors in L2 Listening
}

\author{
Wenjing Li \\ Hangzhou Institute of Commerce, Zhejiang Gongshang University, Hang zhou, China
}

\begin{abstract}
The study used MALQ developed by Vandergrift et al. (2006), an interview and a listening comprehension test to investigate non-English majors' metacognitive awareness in English listening and the relationship between metacognitive awareness and listening comprehension performance. The results revealed a lack of metacognitive awareness in the subjects and a significant discrepancy between good listeners and poor listeners. Since metacognitive awareness is proved to influence listening comprehension in a positive way, teachers are suggested to develop students' autonomous learning ability from this perspective and establish learner-centered listening teaching mode.
\end{abstract}

Index Terms - metacognitive awareness, listening comprehension in English, non-English majors

\section{INTRODUCTION}

Listening comprehension is a crucial part of language acquisition and instruction. It is influenced by many factors, among which metacognitive strategies are most important. Accordingly, language teachers face the challenging task of helping learners develop metacognitive skills. When learners acquire so me metacognitive knowledge, they can manage and evaluate their own language learn ing better. Learners' understanding of mental and emotional processes in their L2 listening can also help them master the ways of improving their listening skills.

This paper will start from an empirical research to explore metacognitive awareness of non-English majors in English listening and the relationship between metacognitive awareness and listening comprehension. The article will conclude with the suggestions to develop learners' metacognitive awareness so as to improve their performance in English listening.

\section{BACKGROUND}

\section{A. Metacognition}

American psychologist Flavell invented the term 'metacognition' in 1970s. It is thinking about one's cognitive process, which includes two essential aspects - "self-appraisal and self-management of cognition" (Paris \& Winograd, 1990, p.17). It refers primarily to "an understanding or perception of ways different factors act and interact to affect the course and outcome of cognitive enterprises" (Goh, 1997, p.361). Flawell identifies three major categories in metacognitive knowledge: personal knowledge; task knowledge and strategic knowledge (Flawell, 1976).

Wenden applies this term into the study of language learning. Metacognitive knowledge refers to "information learners acquire about their learn ing" (Wenden, 1998, P.518). It has also been classified into three categories. Person knowledge is knowledge learners have acquired about themselves as learners (Wenden 1998). It includes "human factors that facilitate or inhibit learning" (Wenden 1998, P.518). Task knowledge is learners' understanding of the purpose and demands of a task, i.e. how to deal with a particular task. Strategic knowledge refers to learners' specific knowledge about the nature of learning strategies and when and how to use them (Wenden 1998).

Besides metacognitive knowledge, metacognitive strategies have been widely acknowledged as a crucial component in metacognition. Metacognitive strategies refer to "general skills through which learners manage, direct, regulate, guide their learning, i.e. planning, monitoring and evaluating" (Wenden, 1998, P.519). Planning refers to the choices of cognitive strategies and allocation of resources. Monitoring refers to the process of keeping track of how the learning task is going on (Wenden 1998). Evaluation is learners' assessment of their learning efficiency and outcomes.

\section{B. The Relationship between Metacognitive Awareness and Listening Comprehension}

It has been argued that metacognition can have positive influence on second language acquisition (Byrnes,1996; Costa, 2001; Sternberg, 1998; Wenden, 1998). Metacognitive abilities "are a mental characteristic shared by successful learners" (Vandergrift, 2006, P.435). Metacognition helps learners understand their learn ing style and capacity, regulate and manage their learning process in an active way, thus finding more effective learning methods. Improvement of metacognition can also help learners become aware of their learning process and demands of learning tasks so that they will know how to choose appropriate learning strategies in different contexts. Consequently, learners can process and restore new information better (Vandergrift, 2006).

Metacognitive awareness in listening refers to the adoption of appropriate strategies and ideal allocation of resources 
(Lin, 2002). Metacognition plays an important role in each phase of listening comprehension. Before approaching the listening task, learners make the prediction, select appropriate strategies (e.g. listening for the main idea) needed for completing it, and distribute attention accordingly. While they are doing the listening task, learners keep or change learning strategies by monitoring their learning process. When they find out that these strategies are ineffective and lead to failure, they seek remedies for facilitating comprehension. When they finish the listening process, they evaluate effectiveness of listening strategies and skills in listening comprehension. Therefore, if the metacognitive theories can be applied in second language listening, learners can become more active participants in the learning process. Learn ing effects and self-regulated learning ability can thus be improved. Their learning interests and motivation can also be generated (Wei, 2008).

\section{Instruments for Measuring Metacognitive Awareness}

There have been some empirical studies to assess metacognitive awareness of listening (Goh, 2002; Vandergrift, 2005), but these questionnaires have some shortcomings. Some are too long (e.g., Goh) and some are not comprehensive enough. (e.g., Vandergrift). Most importantly, none of these self-report instruments followed rigorous validation procedures (Vandergrift, 2006).

In order to develop a re latively short instrument that can elicit and identify L2 listeners' metacognitive awareness and use of strategies when listening to oral texts, Vandergrift designed The Metacognitive Awareness Listening Questionnaire (MALQ) in 2006. It is based on the Flavell's theory and Wenden's model of metacognition (planning, monitoring, evaluating and problem solving) (1998), which provides theoretical validation for item construction. Its reliability and the factorial validity were examined by SPSS. MALQ has been tested with a large nu mber of respondents in many counties and at various levels of language proficiency. It can be used to examine students' perceptions of themselves as listeners, their understanding of tasks, and their awareness of the strategies they use to facilitate listening comprehension.

In China, there is a lack of studies on the difference in metacognitive awareness between skilled and unskilled listeners (Shi, 2009).Th is artic le tries to use Vandergrift's Metacognitive Awareness Listening Questionnaire (MALQ) to diagnose the extent to which non-English majors understand and can regulate their listening process, the difference between good listeners and poor listeners in metacognitive awareness, and the relationship between metacognition and English listening abilities. It is expected to improve teaching of English listening by developing students' metacognitive awareness and self-regulatory abilities.

\section{PRESENT RESEARCH}

\section{A. Research Questions}

The questions to be answered in this research include: 1) To what extent can non-English major be aware of their listening process and strategies used to achieve listening comprehension? 2) Are there any differences between skilled and unskilled listeners in metacognitive awareness? If there is any, in which ways are they different? 3) Is there a relationship between the listening behavior reported in the MALQ and actual listening performance? 4) Do students who score high on MALQ perform better in listening test than who score low?

\section{B. Subjects}

One hundred and thirty-eight non-English majors in Zhejiang Gongshang University participated in this study. They were sophomores from four classes. Their majors were Japanese, finance and accounting. These students' length of learning English ranged from 11 to 13 years. So many years' English learning enabled them to learn some language learning strategies and have their own understanding of L2 listening. That is to say, they had some metacognitive knowledge.

\section{Materials and Procedure}

\section{A listening comprehension test}

A listening comprehension test was administered before the students completed the questionnaire so that they could answer the questions according to their feelings of taking the test. The test was selected from cet- 4 set in December, 2008. The test required students to listen to 8 short conversations, 2 long conversations and 3 short passages and to check comprehension by completing 25 multiple choice questions, with one point each. The test was aimed to measure students' proficiency in L2 listening rather than achievement.

2. The questionnaire

The Metacognitive Awareness Listening Questionnaire (MALQ) (see Table 1) developed by Vandergrift in 2006 was used in this study. In order to ensure full understanding, the researcher used its Chinese version translated by Chans Le (2008).

Immediately following the listening comprehension test, the students were asked to respond to the items using a 6-point Likert scale ranging from "strongly disagree"(one point) to "strongly agree"(six points). Statements 3, 8 a nd 16 were worded negatively so that the respondents would not fall into a pattern of marking only one side of the rating scale. Items 4, 11 and 18 were related to mental translation-strategies language learners should avoid. So for these 6 items, 
researchers needed to reverse the scales when scoring. The score these students got was viewed as their metacognitive awareness of the processes and strategies required for successful second language listening comprehension.

Vandergrift demonstrated a five-factor model underlying the MALQ: planning and evaluation, directed attention, person knowledge, translation and problem-solving (Vandergrift, 2006, P.450). Table 1 consists of 21questions in the questionnaire and the description of each item. (Vandergrift, 2006, P.462).

TABLE 1:

THE DESCRIPTION OF THE FACTORS

\begin{tabular}{|c|c|c|}
\hline Factors & $\begin{array}{l}\text { The description of the } \\
\text { factors }\end{array}$ & Strategy or belief/perception (The statements in the questionnaire) \\
\hline \multirow[t]{5}{*}{ Planning-evaluation } & \multirow{5}{*}{$\begin{array}{l}\text { the strat egies listeners use to } \\
\text { prepare themselves for } \\
\text { listening, and to evaluate the } \\
\text { results of their listening } \\
\text { efforts }\end{array}$} & 1. Before I start to listen, I have a plan in my head for how I am going to listen. \\
\hline & & 10. Before listening, I think of similartext sthat I may have listened to. \\
\hline & & $\begin{array}{l}\text { 14. After listening, I think back to how I listened, and about what Imight do differently } \\
\text { next time. }\end{array}$ \\
\hline & & 20. As I list en, I periodically ask myself if I am sat isfied with my level of comprehension. \\
\hline & & 21. I have a goal in mind as I listen. \\
\hline \multirow[t]{4}{*}{ Directed attention } & \multirow{4}{*}{$\begin{array}{l}\text { strategies that listeners use } \\
\text { to concentrate and to stay on } \\
\text { task. }\end{array}$} & 2. I focus harder on the text when I have trouble understanding. \\
\hline & & 6. When my mind wanders, I recover my concentration right away. \\
\hline & & 12. Itry to get back on track when I lose concentration. \\
\hline & & 16. When I have difficulty understanding what I hear, I give up and stop listening. \\
\hline \multirow[t]{3}{*}{ Person knowledge } & \multirow{3}{*}{$\begin{array}{l}\text { listeners' perceptions } \\
\text { concerning the difficulty } \\
\text { presented by L } 2 \text { listening } \\
\text { and their self-efficacy in L2 } \\
\text { listening }\end{array}$} & $\begin{array}{l}\text { 3. I find that listening in English is more difficult than reading, speaking, or writ ing in } \\
\text { English. }\end{array}$ \\
\hline & & 8. I feel that listening comprehension in English is a challenge for me. \\
\hline & & 15. I don’t feel nervous when I listen to English. \\
\hline \multirow[t]{3}{*}{ Mental translation } & \multirow{3}{*}{$\begin{array}{l}\text { the online mental } \\
\text { translation strat egy. }\end{array}$} & 4. I translate in my head as I listen. \\
\hline & & 11. I translate key words as I listen. \\
\hline & & 18. Itranslate word by word, as I listen. \\
\hline \multirow[t]{6}{*}{ Problem-solving } & \multirow{6}{*}{$\begin{array}{l}\text { strategies used by listeners } \\
\text { to inference (guess at what } \\
\text { they do not understand) and } \\
\text { to monitor these inferences. }\end{array}$} & 5. I use the words I understand to guess the meaning of the words I don't understand. \\
\hline & & 7. As I listen, I compare what I understand with what I know about the topic. \\
\hline & & 9. I use my experience and knowledge to help me understand. \\
\hline & & 13. As I listen, I quickly adjust my interpret ation if I realize that it is not correct. \\
\hline & & $\begin{array}{l}\text { 17. I use the general idea of the text to help me guess the meaning of the words that I } \\
\text { don't understand. }\end{array}$ \\
\hline & & $\begin{array}{l}\text { 19. When I guess the meaning of a word, I think back to everything else that I have heard, } \\
\text { to see if my guess makes sense. }\end{array}$ \\
\hline
\end{tabular}

3. The interview

After the students completed the questionnaire, the researcher interviewed nine randomly selected students, which may allow a detailed interpretation of the result, thereby enhancing the reliability of the study.

\section{RESULTS}

The data was analyzed through SPSS11. 0. The students' level of metacognitive awareness was determined by the analysis of the results of the questionnaire. Besides, the intercorrelations between metacognitive awareness and actual listening behavior were examined by corre lating the MALQ scores with listening comprehension test scores.

Table 2 is the descriptive statistics analysis of whole samples. The table reveals the similarity between the means, medians and the modes. It means the data from MALQ and listening comprehension test present normal distribution, which verifies the validity of data.

TABLE 2:

THE DESCRIPTIVE STATISTICS ANALY SIS OF THE STUDENTS' LEVEL OF METACOGNITIVE AWARENESS AND LISTENING COMPREHENSION ABILITIES.

\begin{tabular}{|l|l|l|l|l|l|l|l|l|}
\hline & number & mean & median & mode & standard deviation & range & maximum & minimum \\
\hline $\begin{array}{l}\text { level of metacognitive } \\
\text { awareness }\end{array}$ & 138 & 3.6529 & 3.6667 & 3.81 & .57196 & 3.19 & 5.14 \\
\hline $\begin{array}{l}\text { listening } \\
\text { comprehension abilities }\end{array}$ & 138 & 11.07 & 11.00 & 11 & 3.627 & 22 & 22 \\
\hline
\end{tabular}

\section{A. The Analysis of Metacognitive Awareness}

Table 3 illustrates the descriptive statistics analysis of the five factors in the Metacognitive Awareness Listening Questionnaire. 
TABLE 3:

THE DESCRIPTIVE STATISTICS ANALYSIS OF THE FIVE FACTORS IN THE METACOGNITIVE AWARENESS LISTENING QUESTIONNAIRE.

\begin{tabular}{|c|c|c|c|}
\hline & items & mean & standard deviation \\
\hline The level of met acognitive awareness & & 3.6529 & .57196 \\
\hline \multirow[t]{6}{*}{ Plan-evaluation } & $1,10,14,20,21$ & 3.4739 & .77782 \\
\hline & 1 & 4.0797 & 1.37794 \\
\hline & 10 & 2.8696 & 1.44902 \\
\hline & 14 & 3.7319 & 1.36985 \\
\hline & 20 & 2.9493 & 1.33631 \\
\hline & 21 & 3.7391 & 1.25159 \\
\hline \multirow[t]{5}{*}{ Directed attention } & $2,6,12,16$ & 4.1304 & 1.15465 \\
\hline & 2 & 3.5362 & 1.58533 \\
\hline & 6 & 4.2681 & 2.97812 \\
\hline & 12 & 4.7464 & 1.12088 \\
\hline & 16 & 3.9710 & 1.36666 \\
\hline \multirow[t]{4}{*}{ Person knowledge } & $3,8,15$ & 2.4879 & 1.09052 \\
\hline & 3 & 2.4565 & 1.44545 \\
\hline & 8 & 2.0580 & 1.23080 \\
\hline & 15 & 2.9493 & 1.46652 \\
\hline \multirow[t]{4}{*}{ Mental translation } & $4,11,18$ & 3.2367 & .84019 \\
\hline & 4 & 2.9058 & 1.21959 \\
\hline & 11 & 2.8188 & 1.24534 \\
\hline & 18 & 3.9855 & 1.20816 \\
\hline \multirow[t]{7}{*}{ Problem-solving } & $5,7,9,13,17,19$ & 4.2742 & .86680 \\
\hline & 5 & 4.0652 & 1.29686 \\
\hline & 7 & 4.1522 & 1.35033 \\
\hline & 9 & 4.5797 & 1.13865 \\
\hline & 13 & 4.0362 & 1.25802 \\
\hline & 17 & 4.4855 & 1.08228 \\
\hline & 19 & 4.3261 & 1.16621 \\
\hline
\end{tabular}

The researcher divided the subjects into two groups according to their score in the listening comprehension test. Those 73 students who scored higher than 11 represented the high-score group and those 65 students who scored lower than 11 belonged to the low-score group. Table 4 shows the results of t-test used to analyze the difference in the level of metacognitive awareness between the high-score group and the low-score group.

TABLE 4:

THE DIFFERENCE IN THE LEVEL OF METACOGNITIVE AWARENESS BETWEEN THE HIGH-SCORE GROUP AND THE LOW-SCORE GROUP

\begin{tabular}{|c|c|c|c|c|c|c|c|}
\hline & group & number & mean & $\begin{array}{l}\text { Standard } \\
\text { deviation }\end{array}$ & $\begin{array}{l}\text { The differences bet ween } \\
\text { the means }\end{array}$ & T value & $\begin{array}{l}\text { the significance } \\
\text { value }\end{array}$ \\
\hline \multirow{2}{*}{$\begin{array}{l}\text { The level of } \\
\text { metacognitive } \\
\text { awareness }\end{array}$} & $\begin{array}{l}\text { high-score } \\
\text { group }\end{array}$ & 73 & 3.7841 & .62457 & \multirow[t]{2}{*}{.2786} & \multirow[t]{2}{*}{2.934} & \multirow[t]{2}{*}{.004} \\
\hline & $\begin{array}{l}\text { low-score } \\
\text { group }\end{array}$ & 65 & 3.5055 & .46874 & & & \\
\hline \multirow[t]{2}{*}{ Plan-evaluation } & $\begin{array}{l}\text { high-score } \\
\text { group }\end{array}$ & 73 & 3.6795 & .75773 & \multirow[t]{2}{*}{.4364} & \multirow[t]{2}{*}{3.415} & \multirow[t]{2}{*}{.001} \\
\hline & $\begin{array}{l}\text { low-score } \\
\text { group }\end{array}$ & 65 & 3.2431 & .73950 & & & \\
\hline \multirow[t]{2}{*}{ Directed attention } & $\begin{array}{l}\text { high-score } \\
\text { group }\end{array}$ & 73 & 4.3356 & 1.33932 & \multirow[t]{2}{*}{.4356} & \multirow[t]{2}{*}{2.245} & \multirow[t]{2}{*}{.026} \\
\hline & $\begin{array}{l}\text { low-score } \\
\text { group }\end{array}$ & 65 & 3.9000 & .85673 & & & \\
\hline \multirow[t]{2}{*}{ Person knowledge } & $\begin{array}{l}\text { high-score } \\
\text { group }\end{array}$ & 73 & 2.6575 & 1.15733 & \multirow[t]{2}{*}{.3601} & \multirow[t]{2}{*}{1.956} & \multirow[t]{2}{*}{.052} \\
\hline & $\begin{array}{l}\text { low-score } \\
\text { group }\end{array}$ & 65 & 2.2974 & .98447 & & & \\
\hline \multirow[t]{2}{*}{ Mental translation } & $\begin{array}{l}\text { high-score } \\
\text { group }\end{array}$ & 73 & 3.3128 & .89774 & \multirow[t]{2}{*}{.1439} & \multirow[t]{2}{*}{1.004} & \multirow[t]{2}{*}{.317} \\
\hline & $\begin{array}{l}\text { low-score } \\
\text { group }\end{array}$ & 65 & 3.1689 & .77027 & & & \\
\hline \multirow[t]{2}{*}{ Problem-solving } & $\begin{array}{l}\text { high-score } \\
\text { group }\end{array}$ & 73 & 4.3744 & .93243 & \multirow[t]{2}{*}{.2129} & \multirow[t]{2}{*}{1.446} & \multirow[t]{2}{*}{.151} \\
\hline & $\begin{array}{l}\text { low-score } \\
\text { group }\end{array}$ & 65 & 4.1615 & .77838 & & & \\
\hline
\end{tabular}

According to the data in table 3 and table 4, the subjects' average score in metacognition is 3.6529 out of 6 , which illustrates a low level of metacognitive awareness of the students in listening. The results reveal that these students are not competent in English listening and lack self-regulation strategies in cognitive activities. In approaching the listening tasks, they are just passive recipients in their performance. To a large extent, they rely on teachers and lack confidence in listening comprehension. 
When comparing the score between the high-score group and the low-score one, the researcher finds a significant difference in their level of metacognitive awareness. The high-score group is better able to regulate their learning and more active in controlling their listening process. That is to say, they are more autonomous in their approach to listening comprehension tasks.

In these five factors in the Metacognitive Awareness Listening Questionnaire, the subjects get the highest score in problem-solving (4.2742). These strategies represent "the problem-solving processes, the knowledge retrieval processes, and the accompanying verification (monitoring) processes" (Vandergrift, 2006, P.462). Learners use what they know to help interpret the text, use the clue in the text to guess the meaning of unknown words, and monitor the accuracy of their inferences with the process of interpretation. The subjects score high in this factor because of their training received in their English class. In the interview, the students told the researcher they had done some cet- 4 exercises in the class and the teachers explained the strategies needed to do the exercises. Most of these strategies belong to the category of problem-solving. Therefore, many subjects are familiar with these strategies and can apply the knowledge into listening comprehension tasks. It also explains why the high-score group and the low-score group show no significant difference in this category.

The mean of directed attention ranks the second and the high-score group and the low-score group show big difference (0.4356). The difference has reached significant level. The students are clear about the importance of maintaining attention because the incoming information disappears in a flash in listening comprehension. The result of the interview reveals that the students who scored low in the listening test are very anxious because of too many difficulties in completing the task. Thus, they are more likely to lose concentration and give up.

The score the subjects got in the factor of plan-evaluation is not high (3.4739) and there is a significant difference between the high-score group and the low-score group (0.4364). The students who were interviewed told the researcher that their teachers placed less emphasis in the strategies of plan-evaluation. Actually, these strategies are difficult to explain in instruction. Many of the strategies are related to monitoring in the listening process and the skills involved are difficult to manage. Consequently, the students are not good at this aspect. According to many researches, good listeners can regulate their learning process. They have goals in mind before approaching the listening task, making adjustments when problems appear and evaluate the effectiveness of their listening strategies after finishing the task. But poor listeners do not show purposeful nature of the comprehension process. They do not have plans so they cannot adopt effective strategies according to different listening tasks. They seldom check their satisfaction with the ongoing interpretation. They do not reflect on their listening efforts afterwards. (Lin, 2002).

The mean of mental translation is also relatively low (3.2367) and the high-score group and the low-score group show no significant diffe rence. This is a strategy learners should avoid in the listening process. If they always translate the information into their mother tongue, the speed of processing information will be very slow. Consequently, they will miss a lot of information and fail to fully understand the listening material. Apparently, these subjects still rely a lot on their mother-tongue, which should be overcome in their English learning.

The subjects scored lowest in personal knowledge (2.4879), with no significant difference between the high-score group and the low-score one. It is possibly because theses subjects are not good at English listening, in which they do not have a lot of practice. Accordingly, they do not have enough confidence in second language listening and avoid the practice. When interviewed, these subjects said they spent more time on vocabulary and reading instead of listening, whether in class or out of class. Thus a vicious circle occurs because lack of successful experience in English leads to low self-efficacy and high level of an xiety in second language listening.

\section{B. The Relationship between Metacognitive Awareness and Listening Performance}

The Pearson correlation coefficient between metacognitive awareness and listening performance is listed in table 5.

TABLE 5:

THE PEARSON CORRELATION COEFFICIENT BETWEEN METACOGNITIVE AWARENESSAND LISTENING PERFORMANCE

\begin{tabular}{|l|l|l|}
\hline \multicolumn{2}{|l|}{ THE PEARSON CORRELATION COEFFICIENT BETWEEN METACOGNITIVE AWARENESSAND LISTENING PERFORMANCE } \\
\hline Metacognitive awareness & Pearson correlation coefficient & Two-tailed significance test \\
\hline Plan-evaluation & $.280(* *)$ & .001 \\
\hline Directed attention & $.331(* *)$ & .000 \\
\hline Person knowledge & $.177(*)$ & .037 \\
\hline Mental translation & $.173(*)$ & .043 \\
\hline Problem-solving & .044 & .607 \\
\hline
\end{tabular}

According to table 5, there is a pattern of intercorrelations between metacognitive awareness and listening comprehension but the correlation is weak (0.280). The result reveals that metacognitive awareness influences listening performance in an indirect way. It only plays a positive role in the organization and planning of listening performance. So it has to work together with other cognitive strategies to improve listening comprehension. Besides, the process of listening comprehension is so complex that it is affected by many other factors, such as age, gender, motivation and learning style. Metacognitive alone cannot determine the result of listening comprehension. In addition, these subjects didn't score high in this listening test because it was too difficult for many of them. Therefore, they are less likely to 
benefit from metacognitive awareness.

Among all the metacognitive strategies, the intercorrelation between planning-evaluation strategies and listening comprehension is significantly high (0.3331). It proves that those students who use more planning, monitoring and evaluation strategies are more likely to perform better in second language listening.

\section{T-test of the Differences in Listening Performance Resulted from Metacognitive Awareness}

Table 6 shows t-test of the influence of metacognitive awareness on listening performance. The subjects are divided into two groups according to the mean of the responses on the survey (3.65),

TABLE 6:

T-TESTOF THE DIFFERENCES IN LISTENING PERFORMANCE RESULTED FROM METACOGNITIVE AWARENESS

\begin{tabular}{|l|l|l|l|l|l|l|}
\hline & $\begin{array}{l}\text { The mean of } \\
\text { met acognitive awareness }\end{array}$ & number & mean & $\begin{array}{l}\text { Standard } \\
\text { deviation }\end{array}$ & $\begin{array}{l}\text { The difference } \\
\text { bet ween the means }\end{array}$ & $\begin{array}{l}\text { T value } \\
\text { value significance }\end{array}$ \\
\hline $\begin{array}{l}\text { Listening } \\
\text { performance }\end{array}$ & $\geq 3.65$ & 70 & 11.90 & 3.773 & 1.69 & 2.811 \\
\hline & $<3.65$ & 68 & 10.21 & 3.281 & & \\
\hline
\end{tabular}

Table 6 reveals that the students with different metacognitive level performed significantly differently in the English listening test. Those with high level of metacognitive awareness scored higher in the test. They can successfully regulate the process of L2 listening comprehension and they are more autonomous in language learn ing. Therefore, thy can fin ish the listening task more effectively. In contrast, those with low level of metacognitive awareness scored lower in the English test because they lack the ability to regulate their cognitive activities. They cannot consciously monitor or evaluate their process of L2 listening.

\section{Summary}

This research has produced the following results:

1. These non-English majors do not show high level of metacognitive awareness. According to the means they reported in each category of metacognitive strategies from high to low, the order is problem-solving, directed attention, plan-evaluation, mental translation and person knowledge.

2. The high-score group and the low-score group show significant difference in metacognitive awareness. Among those five categories, the difference in planning-evaluation and directed attention is significant.

3. There is a weak correlation between metacognitive awareness and listening comprehension. Those who report higher mean of plan-evaluation are more likely to have higher L2 listening ability.

4. There is a significant difference between the students with different metacognitive levels.

\section{DISCUSSION}

From this survey and test, the researcher draw the conclusion that these non-English majors lack metacognitive awareness in second language listening, especially self-efficacy. Teachers can help them improve their metacognitive aware in the following ways.

Firstly, MALQ can be used to determine the students' current level of metacognitive awareness and help them understand their problems from an objective perspective. It can also be used to make the students become more aware of their listening process and relative cognitive activities.

Secondly, the students' metacognitive knowledge should be enriched. The result of the research reveals that there is only weak correlation between metacognitive strategies and proficiency in L2 listening comprehension. Metacognitive knowledge can be effective only if it is applied into practice. So, in English teaching, teachers should help the students combine metacognitive knowledge with listening practice and introduce listening comprehension strategies according to different tasks. In this way, the students can apply metacognitive strategies into specific contexts and understand the functions of metacognition in the practice.

Thirdly, various ways can be tried to improve learners' monitoring abilities. Teachers can organize the discussion among students on metacognition. Discussion may focus on a certain topic, such as "how to practice second language listening after class", or "which listening tasks are helpful in improving listening abilities". It can also center around a certain listening task. Before doing the task, the students can discuss its specific objective, strategies that can be used, potential problems and ways to solve those problems. After they complete the task, they may discuss effectiveness of the strategies and the factors that contribute to success in finishing the listening task. In this way, the students can understand the functions of metacognition in a comprehensive way and identify the factors that may lead to success and failure in their listening practice. Thus, they can conscious ly use appropriate strategies in other listening tasks.

Fourthly, given the fact that non-English majors do not have many English classes, teacher should guide the students in spending more time after class in practicing English listening. Large amount of listening practice is a prerequisite for improving listening abilities. And only in listening practice can students fully understand the importance of metacognition. Teachers can ask the students to make appropriate plans in accordance with their own abilities. When choosing listening materials after class, the students should avoid those far beyond their abilities. In experiencing success repeatedly, the students can gradually gain confidence in English listening. 
In summary, through training in metacognitive strategies, students can shoulder more responsibilities in the process of learn ing and learner autonomy can be promoted. When the students can control their learning effectively, they will become more interested in language learning. As a result, they are more willing to invest more time in autonomous learning in English listening after class. To help students become more autonomous and successful learners is the ultimate objective of language teaching.

\section{CONCLUSION}

This research investigated the metacognitive awareness of non-English majors in English listening and the relationship between metacognitive awareness and listening comprehension. This study is limited both by the small size of the participants and the nature of the listening test. A study of this should be replicated with more different groups of learners. Future studies should also use listening materials which are more authentic and closer to the students' current listening level. Finally, how to give the students training in metacognitive strategies and shorten the distance between metacognitive knowledge and listening practice provides a large research area for further research.

\section{REFERENCES}

[1] Byrnes, J. P. (1996). Cognitive development and learning in instructional contexts. Boston: Allyn \& Bacon.

[2] Chang Le, Li Linlin. (2008). A correlation study between Chinese university English learners' metacognitive awareness and their listening comprehension. Foreign Language Education in China 1/4: 45-54.

[3] Costa, A. L. (ed.). (2001). Developing minds: A resource book for teaching thinking (3rd ed.). Alexandria, VA: Association for Supervision and Curriculum Development.

[4] Flavell, J. H. (1976). Metacognitive aspects of problem solving. In L. B. Resnick (ed.). The Nature of Intelligence. Hillsdale, $\mathrm{NJ}$ : Erlbaum.

[5] Goh, C. (1997). Metacognitive awareness and second language listeners. ELT Journal 51/4: 361-9.

[6] Goh, C. (2002). Learners' self-reports on comprehension and learning strategies for listening. Asian Journal of English Language Teaching 12: 46-68.

[7] Lin. Qiong. (2002). A metacognitive study on unsuccessful listeners. Foreign Language World 88/2: 40-44.

[8] Paris, S.G. and P.Winograd. (1990). 'How metacognition can promote academic learning and instruction' in B.F. Jones and L. Idol (eds.): Dimensions of Thinking and Cognitive Instruction. Hillsdale, NJ: Lawrence Erlbum Associates.

[9] Shi Yu. (2009). Review of the metacognitive research abroad on second language listening. Foreign Language World 1: 57-63.

[10] Sternberg, R. J. (1998). Metacognition, abilities and developing expertise: What makes an expert student? .Instructional Science 26: $127-140$.

[11] Wei Xinqiang. (2008). Study on the Relationship between Metacognition and Self - access Listening. Journal of North China Institute of Water Conservancy and Hydroelectric Power( Social Science) 24/2: 131-133.

[12] Wenden, A. (1998). Metacognitive knowled ge and language learning. Applied Linguistics 19: 515-537.

[13] Vandergrift, L. (2005). Relationships among motivation orientations, metacognitive awareness and proficiency in L2 listening. Applied Linguistics 26(1): 70-89.

[14] Vandergrift L \& Goh C. (2006). The metacognitive awareness listening questionnaire: development and validation. Language Learning 56/3: 431-462.

Wenjing Li holds a MA degree in applied linguistics from Zhejiang University in China. Her research interest lies in linguistics and investigation of language teaching strategies. She is now teaching in Zhejiang Gongshang University. She has recently published in Journal of Culture \& International Lan guages 